\title{
Olimpiese goud, 2008
} \author{
in twee verdeel: \\ lug en spieël \\ die gespierde bene gereed \\ om elasties vas te trap en hom op te skiet \\ die tone volmaak gespits \\ om perfek die hoogste punt te bereik \\ die eweredige goue lyf \\ om hom in volkome ewewig hangend te hou \\ die gebalanseerde arms \\ om hom soos met vlerke swewend neer te lei \\ die binne-oor só gereël \\ om \\ bo en onder \\ links en regs \\ alles buite presies te verbeel.
}

Op die duikplank wag die Chinese meneer He bo sy terrein

Die brons en silwer word uitgedeel.

Meneer He se goue skyf hang om sy nek.

Skaam kyk hy op:

skeel.

\begin{tabular}{|c|c|c|}
\hline & & Author: Heinrich van der Mescht ${ }^{1}$ \\
\hline \multirow{5}{*}{ 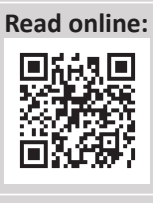 } & \multirow{5}{*}{$\begin{array}{l}\text { Scan this QR } \\
\text { code with your } \\
\text { smart phone or } \\
\text { mobile device } \\
\text { to read online. }\end{array}$} & Affiliation: ${ }^{1}$ Music Department, University of Pretoria, South Africa \\
\hline & & Correspondence to: Heinrich van der Mescht \\
\hline & & Email: heinrichvandermescht@gmail.com \\
\hline & & Postal address: Private Bag X20, Hatfield 0028, South Africa \\
\hline & & $\begin{array}{l}\text { How to cite this article: Van der Mescht, H., 2015, 'Olimpiese goud, 2008', Literator 36(1), Art. \#1118, } 1 \text { page. } \\
\text { http://dx.doi.org/10.4102/lit.v36i1.1118 }\end{array}$ \\
\hline & & Copyright: (C) 2015. The Authors. Licensee: AOSIS OpenJournals. This work is licensed under the Creative Commons Attribution License. \\
\hline
\end{tabular}

